\title{
Reply to query: Cerebrospinal fluid tests for neurosyphilis diagnosis by Drago et al
}

\author{
Fareed Shiva
}

Genitourinary Medicine and HIV, Imperial College Healthcare NHS Trust, London, UK

\section{Correspondence to}

Dr Fareed Shiva, Genitourinary Medicine and HIV, Imperial College Healthcare NHS Trust, London W2 1NY, UK; fareed. shiva@nhs.net

Published Online First 4 May 2020

\section{Linked}

http://dx.doi.org/10.1136/

sextrans-2020-054465

- http://dx.doi.org/10.1136/

sextrans-2019-054198

D Check for updates

(C) Author(s) (or their employer(s)) 2020. No

commercial re-use. See rights and permissions. Published by BMJ.

To cite: Shiva F.

Sex Transm Infect

2020:96:388
With regard to the trend of Cerebrospinal Fluid (CSF) Treponema Pallidum Particle Agglutination (TPPA) titres over time in our cohort, no significant changes in CSF TPPA titres were observed after treatment of individuals. The titres had either remained the same or showed a decrease of onefold over 6 months. Longerterm follow-up CSF TPPA titre values is not available. The diagnostic value of CSF TPPA titre of $>1: 320$ is shown in the study by Marra et al $;{ }^{1}$ however, the value of CSF TPPA titre in monitoring response to treatment has not been established.
Funding The authors have not declared a specific grant for this research from any funding agency in the public, commercial or not-for-profit sectors.

Competing interests None declared.

Patient consent for publication Not required.

Provenance and peer review Not commissioned; internally peer reviewed.

ORCID iD

Fareed Shiva http://orcid.org/0000-0001-7746-9657

\section{REFERENCE}

1 Marra CM, Maxwell CL, Dunaway SB, et al. Cerebrospinal fluid Treponema pallidum particle agglutination assay for neurosyphilis diagnosis. J Clin Microbiol 2017;55:1865-70. 